Article

\title{
Simulation-Based Evaluation of the Effect of Green Roofs in Office Building Districts on Mitigating the Urban Heat Island Effect and Reducing $\mathrm{CO}_{2}$ Emissions
}

\author{
Yujiro Hirano ${ }^{1, *(D)}$, Tomohiko Ihara ${ }^{2} \mathbb{D}$, Kei Gomi $^{1}$ and Tsuyoshi Fujita ${ }^{3}$ \\ 1 Fukushima Branch, National Institute for Environmental Studies, Fukushima Environmental Creation \\ Centre, 10-2 Fukasaku, Miharu Town, Tamura District, Fukushima 963-7700, Japan; gomi.kei@nies.go.jp \\ 2 Department of Environment Systems, Graduate School of Frontier Sciences, The University of Tokyo, 5-1-5, \\ Kashiwanoha, Kashiwa, Chiba 277-8563, Japan; ihara-t@k.u-tokyo.ac.jp \\ 3 Center for Social and Environmental Systems Research, National Institute for Environmental Studies, 16-2, \\ Onogawa, Tsukuba, Ibaraki 305-8506, Japan; fujita77@nies.go.jp \\ * Correspondence: yhirano@nies.go.jp; Tel.: +81-247-61-6572
}

Received: 27 February 2019; Accepted: 26 March 2019; Published: 6 April 2019

check for updates

\begin{abstract}
This study focused on the effects of green roofs in office building districts. The purpose of this study was to evaluate the effectiveness of green roofs in the reduction of the urban heat island (UHI) effect and $\mathrm{CO}_{2}$ emissions. These effects consider decreased energy consumption for space cooling, and the amount of water needed for evapotranspiration on the green roofs. A coupled urban canopy/building energy model (CM-BEM) was utilized to simulate the effectiveness of green roofs. The amount of water needed for evapotranspiration was calculated by using latent heat flux, which was derived from the results of roof surface heat balance calculations. The effect of green roofs on $\mathrm{CO}_{2}$ emissions was determined based on their effectiveness to reduce the energy demand for space cooling, calculated by air-conditioning load simulation. We calculated the $\mathrm{CO}_{2}$ emissions from powering the pumps and the use of tap water, when the necessary amount of water was supplied by watering. Finally, the relationships between amount of water, $\mathrm{UHI}$ mitigation, and $\mathrm{CO}_{2}$ emissions were determined.
\end{abstract}

Keywords: green roof; evapotranspiration; watering; urban heat island; meteorological simulation; $\mathrm{CO}_{2}$ emission

\section{Introduction}

In recent years, global warming has intensified and the need to reduce energy consumption and $\mathrm{CO}_{2}$ emissions has increased [1,2]. Rising temperatures due to urbanization, i.e., urban heat island (UHI) effect, are aggravating [3-8]. The loss of comfort increases the energy consumption for cooling during the summer in urban spaces $[9,10]$. Therefore, it is important to reduce the cooling demand and improve the thermal environment in urban areas to save energy and mitigate the impacts of global warming.

The introduction of green roofs is a strategy that can improve the urban thermal environment and reduce energy consumption for cooling [11-17]. Although urban vegetation is known to be effective for temperature reduction through transpiration, there is a limited space for on-ground greening of urban areas $[18,19]$. Thus, in recent years, roof greening has become an attractive alternative.

As mentioned above, improvement of the urban thermal environment is an important issue linked to the measures being taken against global warming, and hence, it needs to be incorporated into the 
environmental policy of the local government. Therefore, it is necessary to quantify the effect not only on a building scale, but also on the urban scale when it is introduced to a large number of buildings. A decision support system has been developed to evaluate the measures against UHI by land use planning [20], and the UHI effect of urban green areas can also be evaluated. However, this system does not include building-scale measures, such as the introduction of green roofs. Therefore, there is an urgent need to establish a method to understand the UHI mitigation effect on an urban scale when building-scale measures are widely applied.

Many existing studies on green roofs are based on actual observations conducted by installing test specimens on the roof surface. For example, Takebayashi and Moriyama [21] observed the surface temperature, net radiation, water content ratio, etc., of green roof specimens installed on a building rooftop and investigated the estimation method for the sensible heat flux from the roof surface. Ayata et al. [22] measured sensible heat fluxes on a green roof under different environmental conditions by using an experimental laboratory setup. Huang et al. [23] compared the reductions in temperature and heat amplitude achieved by adopting four types of extensive green roofs. Coutts et al. [24] compared the insulating properties, radiation, and surface energy balance of four experimental rooftops, including a green roof planted with sedum. Collins et al. [25] measured the thermal conductivity and equivalent thermal resistance of the green roof system during winter conditions to understand how green roofs affect building energy performance under cold climatic conditions. Dvorak et al. [26] monitored the temperatures and soil water content of three types of plants and one unplanted control module to understand rooftop temperature reductions of unirrigated green roofs. Jiang et al. [27] evaluated the thermal performance of extensive green roofs to understand the temperature reduction and heat flux of extensive green roofs combined with night ventilation by using experimental cells installed on a building rooftop. In these studies, although detailed observations of heat flux and surface temperature could be conducted at this scale, determining factors such as the cooling energy consumption and resulting $\mathrm{CO}_{2}$ emissions is difficult. Thus, it is a challenge to directly link their results with the evaluation of policies from the aforementioned perspective of measures to address global warming. There are also studies on the quantification of the effect of green roofs based on actual measurements of various buildings where green roofs have actually been introduced; examples of such buildings are a low-rise commercial building in Singapore [28], a complex public/private facility "Acros Fukuoka" in Japan [29], the Climate Change Research Hall of National Institute for Environmental Studies in Japan [30], an office building located at the Gardeny Science and Technology Park in Spain [31], the Nicholas J. Pirro Convention Center in New York [32], and the buildings of universities and a private company in Hong Kong [33]. The energy savings effect of green roofs has also been evaluated on a building scale, using air conditioning load calculation, by air conditioning load calculation being linked to observation results $[27,34]$. However, these studies are limited to the evaluation of a single or at most several buildings. In many cases, the outside air temperature of the surrounding atmosphere in the urban block hardly changes by the greening of a few buildings. Therefore, using such measurements to quantify the effect of green roofs on multiple buildings for the adoption of future policies has limitations in that they cannot provide findings that could contribute to decision-making by local governments.

The evaluation of large-scale effects requires urban district-scale simulations of the studied thermal environment. Many studies have already been conducted on the development of models to simulate the microclimate in urban canopies such as: the urban canopy parameterization (UCP) with building energy model (BEM) [35,36], the canopy interface model (CIM) with CitySim [37], the weather research and forecasting (WRF) model coupled to a multilayer building energy scheme [38], the WRF with the urban canopy model [39], the coupled urban canopy and building energy model (CM-BEM) [40-47], architectural-urban-soil-simultaneous simulation model (AUSSSM) [48,49], the urban climate simulation system (UCSS) [50,51]. Surface energy balance measurements in an urban canopy and estimations of the anthropogenic heat release have also been conducted with a modeling perspective [52]. Simulations linking local meteorological models and air-conditioning 
loads have already been conducted, as well as evaluations of UHI mitigation and reduction of energy consumption for space cooling by green roofs [39-42,48-51].

To calculate energy consumption other than through air-conditioning load calculation, we proposed a technique that combines intensity and temperature sensitivity methods [53]. This technique can be used to quantify the effects of green roofs on air-conditioning energy consumption. However, only the changes in outdoor temperatures can be estimated by this method, not the changes in building surface temperature. Therefore, the most realistic approach to estimate the effects of green roofs on the energy consumption of air conditioners is the simulation-based evaluation using air-conditioning load calculation.

The local climate and weather conditions have a significant effect on this type of evaluation. The results depend on the type of greening and the building structure. In many cases of simulation-based evaluation at the district scale [39-42,48-51], surface wetness is parameterized as a fixed value of evaporation efficiency, evaporation ratio, and water vapor transfer conductance. Latent heat flux is calculated from the set parameters, and atmospheric and surface conditions. Calculations are generally performed without considering the amount of water and assuming that evapotranspiration continues indefinitely. However, in many cases, there are constraints on the water supply of a closed environment of a building rooftop. Therefore, the amount of water needed for evapotranspiration should be quantified to evaluate the effectiveness of green roofs under these conditions.

Latent heat flux can be regarded as a function of evapotranspiration. Thus, if irrigation is performed, the amount of water can be converted and quantified as heat. Since the volumetric heat capacity of air is regarded as a known quantity, we assume that the sensible heat flux decreases by the same amount that the latent heat flux increases. It is also assumed that the temperature reduction effect in response to the amount of watering depends only on atmospheric diffusion. We have previously derived a relationship between on-ground watering and temperature [54] at the scale of a few kilometers using a mesoscale meteorological model. However, the study did not provide detailed data on the temperature reduction effect at the district scale. In addition, our previous research [54] focused only on on-ground watering and did not cover the effects of green roofs and accompanying reduction in cooling energy. Many previous simulations did not consider the amount of water used, despite building roofs being mostly under closed conditions, where water is supplied through an irrigation system. Therefore, to properly evaluate the mitigation effects of green roofs in an urban thermal environment, it is necessary to conduct a detailed evaluation that combines air/surface temperature, surface heat balance, and supplied amount of water.

If the green roof is irrigated, the environmental load incorporates several new factors, such as energy consumption to power the water pumps. However, there is a limited amount of research that focus on the environmental load of green roofs.

Given this background, the purpose of this study was to quantify the effectiveness of green roofs in office building districts to mitigate $\mathrm{UHI}$ and $\mathrm{CO}_{2}$ emissions. For that, a simulation of the urban thermal environment considering water volume for evapotranspiration and irrigation was performed. In many previous studies, surface wetness has been parameterized as a constant value, and simulations were conducted assuming that evaporation continues indefinitely in accordance with the atmospheric conditions [39-42,48-51]. However, a building rooftop is a relatively closed environment in comparison with natural environments. Thus, the amount of water supplied through irrigation and precipitation often act as a constraint for evapotranspiration. Therefore, the supplied amount of water needed to be estimated for a more realistic evaluation. Additionally, in many previous simulations, the results depended on given parameters of surface wetness, such as evaporation efficiency. However, since latent heat flux is a function of the amount of water alone, it is possible to derive a clearer physical relationship by directly linking the amount of water used for evapotranspiration to the latent heat flux. In addition, by analyzing the amount of watering, it is possible to add factors, such as $\mathrm{CO}_{2}$ emissions from powering the pumps and the use of tap water, to the items being examined. Therefore, the originality 
of this research lies in the evaluation of the green roof effects by quantifying the evapotranspiration using latent heat flux and considering the necessary amount of watering. We calculated the $\mathrm{CO}_{2}$ emissions from irrigation in a previous study [43], where the surface wetness was expressed by a given parameter of water vapor transfer conductance, but the validation was not complete. Therefore, in this study, we first modified the calculations of the previous report [43] based on observations of the rooftop of an office building [30]. Next, we evaluated the relationship between the amount of evapotranspiration and the cooling effect. Further, by conducting numerical experiments under various conditions, the $\mathrm{UHI}$ mitigation and $\mathrm{CO}_{2}$ reduction due to green roofs were quantified.

\section{Calculation Conditions}

The CM-BEM [40-47] was used in this study to predict the heat load of the buildings in urban districts, the energy consumption by air-conditioning, and the air temperature variations. The urban canopy model (CM) is a local meteorological model that expresses a horizontally homogeneous city-block composed of an array of square buildings as multiple one-dimensional vertical layers. The model considered the following parameters: average building width, building interval, and vertical distribution of building density. The building energy model (BEM) calculates air-conditioning loads. Air-conditioning loads that include interaction with the outside atmosphere in a city-block scale can be calculated by combining both models.

In our previous study [43], the conductance in the vegetation surface was set as a constant value. Based on that and on atmospheric conditions, the evaporation efficiency was calculated. However, in practice, it was difficult to obtain precise vegetation conductance values on green roof surfaces that are being watered. Therefore, in this study, the model was modified so that the evaporation efficiency on the green roof surface is constant based on the measurement results [30] (except for the low evaporation efficiency condition in Section 5).

Evaporation efficiency can be estimated from the following bulk equations [30]:

$$
\begin{aligned}
H & =c_{P} \rho C_{H} U\left(T_{S}-T_{a}\right) \\
l E & =l \rho C_{E} U\left(q_{S A T}-q\right) \\
& =l \rho \beta C_{H} U\left(q_{S A T}-q\right)
\end{aligned}
$$

where, $H$ : sensible heat flux; $l E$ : latent heat flux; $c_{p}$ : specific heat of air; $\rho$ : air density; $T_{a}$ : air temperature; $T_{S}$ : surface temperature; $U$ : wind speed; $q_{S A T}$ : saturation specific humidity for the surface temperature; $q$ : specific humidity of the air; $C_{H}$ : bulk transfer coefficients for sensible heat flux; $C_{E}$ : bulk transfer coefficients for latent heat flux; and $\beta$ : evaporation efficiency. The latent heat flux was estimated based on the time change of the weight of the greening sample. The sensible heat flux was estimated based on the Bowen ratio, which was calculated from the temperature and humidity observed at two points with different heights. Moreover, evaporation efficiency $\beta$ was calculated from the ratio between the bulk transport coefficient of sensible heat and latent heat $\left(C_{E} / C_{H}\right)$. As a result, the evaporation efficiency was generally stable (approximately 0.2 ). Therefore, the evaporation efficiency was set as a constant value of 0.2 in this study. This constant value implies that the wet state of the surface is maintained through watering. We calculated the amount of water based on the latent heat flux obtained from the heat balance calculation.

Figure 1 shows the district model evaluated in this research. Three levels of roof greening were considered: $0 \%$ (no greening), $50 \%$, and $100 \%$. In addition, details such as the wall surface structure, operation schedule of air conditioner, composition of heat source equipment, bodily heat production, and equipment (other than air conditioner) heat production were based on the parameters for a typical office district simulation by Kikegawa et al. [40], and Hirano and Fujita [42] (Table 1). 
(a) Schematic diagram of the model structure

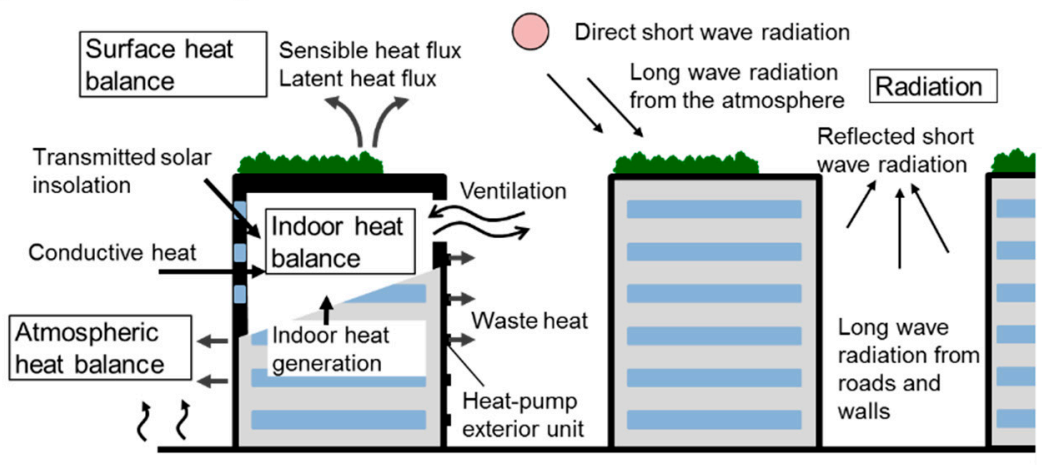

(b) Geometric settings and greening scenarios

\section{Rooftop greening area:} three levels $(\underline{\mathbf{0} \%}, \underline{\mathbf{5 0} \%}$, and $\underline{\mathbf{1 0 0} \%})$ of roof area

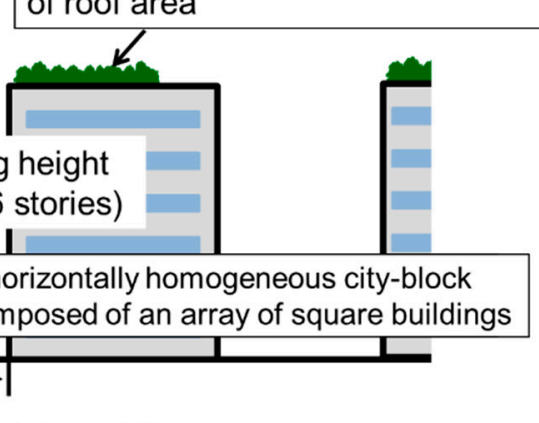

\section{Building width $\underline{16 \mathrm{~m}} \quad$ Building interval $\underline{12 \mathrm{~m}}$}

Figure 1. Overview of the proposed model.

Table 1. Assumed parameters conditions and values.

Temperature Setting for Cooling $\left({ }^{\circ} \mathrm{C}\right)$

Humidity setting for cooling (relative humidity: \%)

Total transmission of solar insolation at window surface (-)

Amount of outside air introduced per floor area $\left(\mathrm{m}^{3} / \mathrm{m}^{2} / \mathrm{h}\right)$

Position of air vent (for introducing outside air)

Occupied floor area per person $\left(\mathrm{m}^{2} /\right.$ person)

Air-conditioned area as a percentage of building total floor area (-)

Heat produced by human bodies per floor area $\left(\mathrm{W} / \mathrm{m}^{2}\right)$

Building floor height ( $\mathrm{m} /$ floor)

Thermal transmittance of outer walls $\left(\mathrm{W} / \mathrm{m}^{2} / \mathrm{K}\right)$

Heat capacity per cross-sectional area of outer walls $\left(\mathrm{J} / \mathrm{m}^{2} / \mathrm{K}\right)$

Heat source supply (system or equipment) (\%)

26.0
50.0
0.3
3.0
ach floor
10.0
0.75

Sensible heat: 6.27

Latent heat: 5.34

3.5

0.68

$3.11 \times 10^{5}$

Absorption type (city gas): $33.1 \%$ Electric heat pump: $66.9 \%$

The calculations were performed on 8-10 August 2002, a period of consecutive fair-weather summer days in Tokyo. The first two days were considered a run-up calculation period, and the third day was used for the analysis. The $\mathrm{CO}_{2}$ emission intensity was $0.371\left(\mathrm{~kg}-\mathrm{CO}_{2} / \mathrm{kWh}\right]$ for electric power and $2.08\left(\mathrm{~kg}-\mathrm{CO}_{2} / \mathrm{m}^{3}\right.$ ] for city gas. The heat production per volume was set as $44.8\left(\mathrm{MJ} / \mathrm{m}^{3}\right)$.

The electric power sensitivity to temperature was verified through comparison with power supply data [45]. Reproducibility was ensured through comparison with air-conditioning load calculation software for homes [40]. In addition, for the condition assumptions, reproducibility of outdoor weather elements was verified through meteorological observations in the district [46]. We conducted a cross-comparison between the energy consumption estimation method [53] and the air-conditioning load calculation using CM-BEM, and no major deviations were observed [55]. 


\section{Evaluation of UHI Mitigation Effect}

Figure 2 depicts the diurnal variation patterns of the rooftop surface temperature calculated under the assumed conditions for the no-greening (concrete) and 100\% greening cases. For comparison, air temperature at the rooftop level is also depicted. The values of air temperature almost overlap each other. The maximum air temperature difference between the two cases was $0.13^{\circ} \mathrm{C}$, which is extremely small compared with the surface temperature differences. As seen in Figure 2, a temperature difference of around $10{ }^{\circ} \mathrm{C}$ between the surfaces occurs during the day. There was a significant temperature reduction on green roofs. In contrast with the vegetated surface, the temperature of the concrete surface constantly exceeded the air temperature at night, except for a very short period in the early morning, mainly due to the amount of heat stored during the daytime. The vegetation surface had a consistently lower temperature than the air temperature at night because of the differences in the radiative cooling effect.

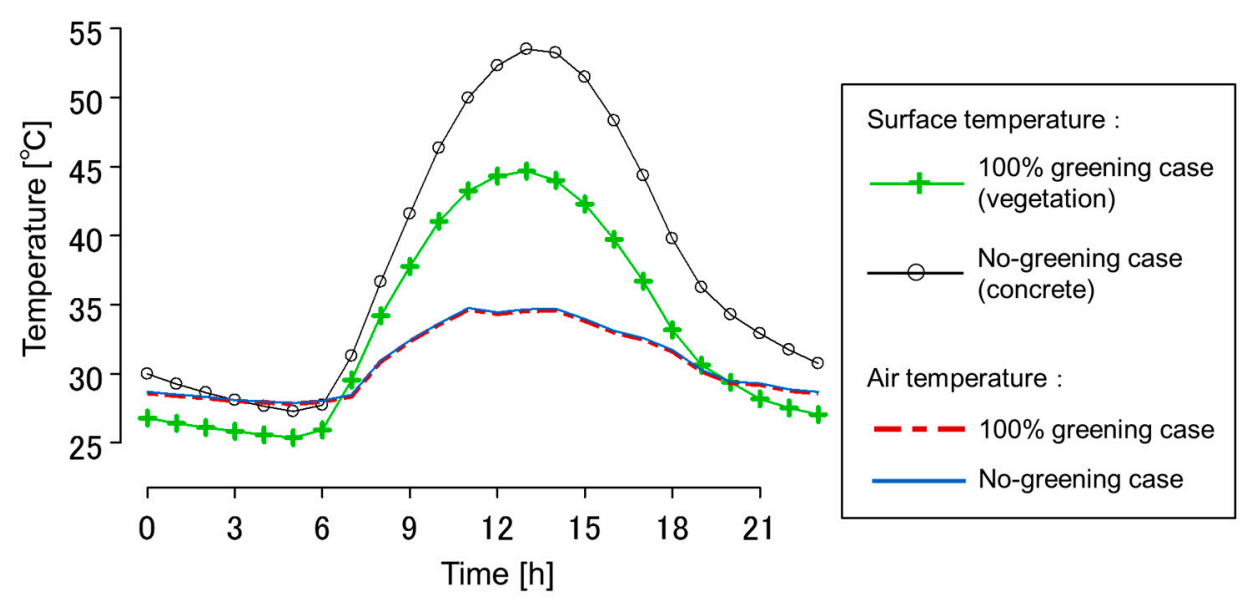

Figure 2. Temperature of the air and of concrete and vegetation surfaces on a rooftop.

A similar examination was conducted for the $50 \%$ greening case. The concrete surface in the $50 \%$ greening case almost matched the no-greening case, and the vegetation surface almost matched the $100 \%$ greening case. The differences in daily averages were less than $0.1{ }^{\circ} \mathrm{C}$ (the graph is not shown). Air temperature and humidity near the rooftop varied when the area over which the roof greening was introduced. Therefore, there were some differences in the surface temperature, but the effect was extremely small compared with the total variation in surface temperature.

The roof surface heat balance was plotted for the no-greening and 100\% greening cases (Figure 3). Positive values were assumed for the direction in which heat enters the surface. The graph shows that, in the $100 \%$ greening case, about half of the net radiation was released into the atmosphere as latent heat flux. In the $50 \%$ greening case, the same examination conducted for the vegetation and concrete surfaces showed that the vegetation surface matched well with the $100 \%$ greening case, and the concrete surface matched well with the no-greening case.

The measurements taken by the authors on a roof surface with sedum greening demonstrated that during the day, the evaporation efficiency was 0.2 , and the latent heat flux was $300-400 \mathrm{~W} / \mathrm{m}^{2}$. In addition to that, the Bowen ratio was 0.5 [30]. Naturally, the surface heat balance depends on weather conditions, but the latent heat flux and the Bowen ratio roughly match Figure 3b. Even if the comparison was done against a heat balance simulation of the Earth's surface [56,57], the results shown in Figure $3 b$ are still valid.

In numerical experiments, the evaporation efficiency was varied in regular intervals using a mesoscale meteorological model. Almost all of the net radiation was released into the atmosphere as latent heat flux when the evaporation efficiency exceeded 0.5 (fair summer weather conditions) [54]. The results were highly dependent on the wetness of the surface. 
(a) No-greening case (concrete)

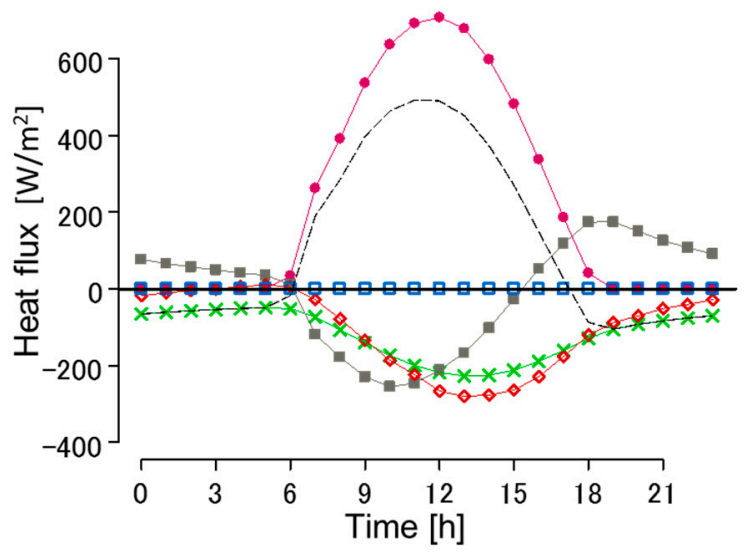

(b) $100 \%$ greening case (vegetation)

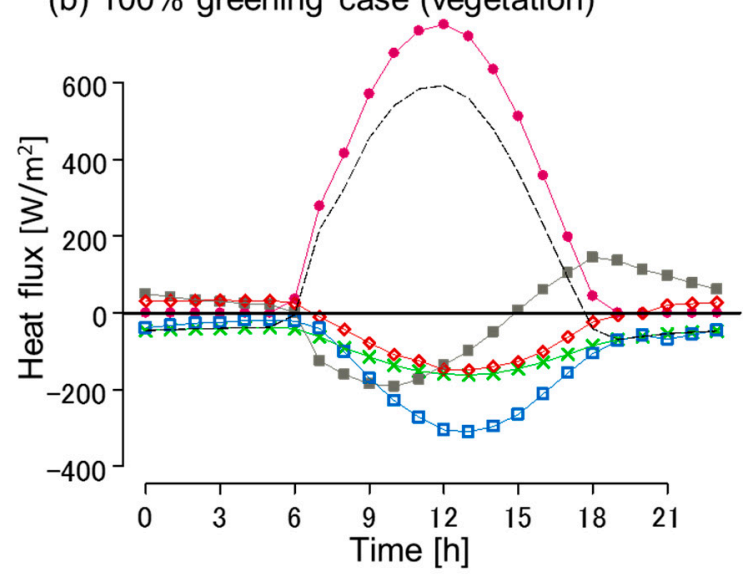

- Net shortwave radiation $\times$ Net longwave radiation

- Heat conduction $\diamond$ Sensible heat flux

- Latent heat flux

----- Net radiation (shortwave + longwave)

Figure 3. Surface heat balance on the rooftop.

The relationship between the results for evapotranspiration and the air temperature reduction effect is shown in Figure 4. The period from 7 a.m. to 6 p.m. was designated as "day", and from 7 p.m. to 6 a.m. as "night". The air temperature reduction effect was calculated using the differences between the cases, which were based on average air temperature of all layers from the ground to the rooftop in the urban canopy. However, even during the day in the $100 \%$ greening case, the maximum temperature reduction effect was $0.13{ }^{\circ} \mathrm{C}$, which is small compared to the total variation in air temperature. These results are consistent with those obtained by Santamouris [12], who reviewed a large number of studies and concluded that, although the temperature reduction effect of green roofs varies, greatly depending on regional conditions and other factors, when green roofs are installed in high-rise buildings, the effect on the surrounding air temperature can be almost negligible.

(a) Diurnal variation pattern
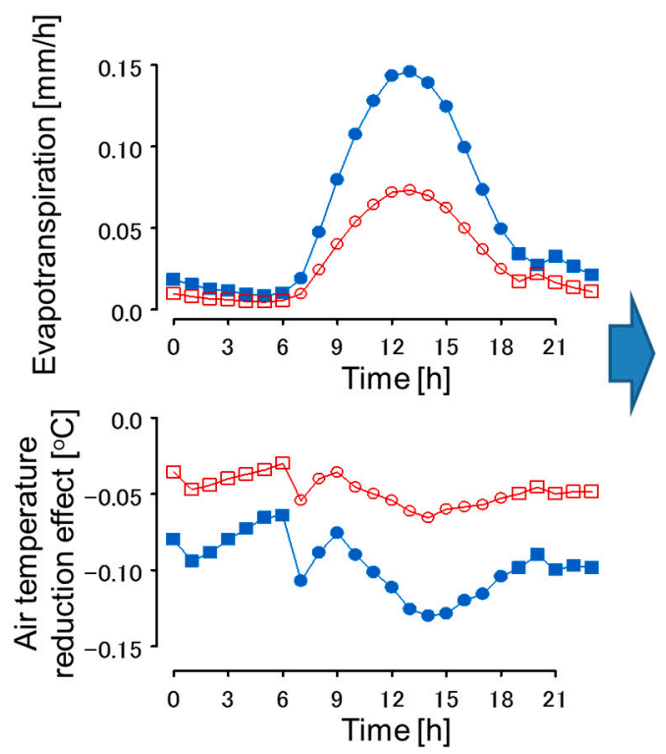

(b) Scatter diagram

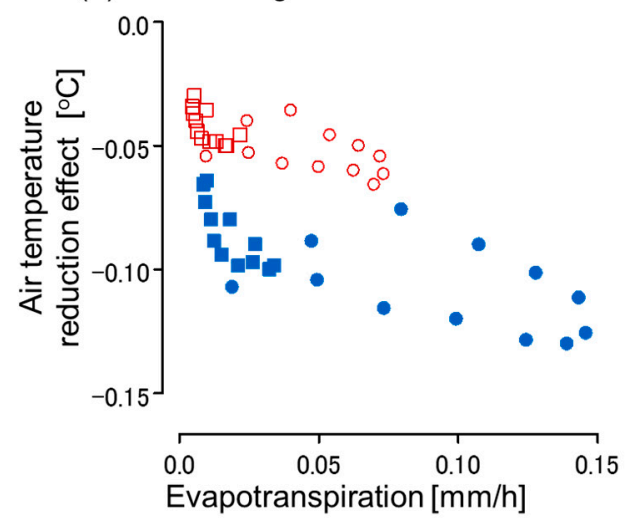

Case with $100 \%$ greening

:Daytime : Night

Case with $50 \%$ greening

$\circ$ :Daytime $\square:$ Night

Figure 4. Relationship between evapotranspiration and temperature reduction.

The amount of evapotranspiration was calculated using the latent heat flux shown in Figure 3. The amount of water needed per building was $1.1\left(\mathrm{~m}^{3} / \mathrm{d}\right)$ in the $100 \%$ greening case and $0.55\left(\mathrm{~m}^{3} / \mathrm{d}\right)$ 
in the $50 \%$ greening case. The evapotranspiration per district area was $1.34(\mathrm{~mm} / \mathrm{d})$ for the $100 \%$ case, and $0.71(\mathrm{~mm} / \mathrm{d})$ for the $50 \%$ case. The numbers of evapotranspiration values for the entire district are shown in Figure 4. The comparison between the cases in Figure 4 show that the air temperature effect in the $100 \%$ greening case was twice the decrease in the $50 \%$ greening case at all times. As latent heat flux is a function of evapotranspiration alone, the results showing that the temperature reduction effect varies almost in proportion with evapotranspiration are valid.

If results from different times are compared within the same case, the relationship will not necessarily be proportional because atmospheric diffusion varies each hour, and the temperature reduction analysis includes the effects up to the previous time. In Figure 4, evapotranspiration and temperature reduction effect were high during the day. However, there was a tendency for the temperature reduction effect per evapotranspiration to be smaller than at night because although evapotranspiration is greater during the day, the surrounding air can more easily diffuse away.

\section{Evaluation of the $\mathrm{CO}_{2}$ Reduction Effect}

To evaluate the $\mathrm{CO}_{2}$ reduction effect of roof greening, $\mathrm{CO}_{2}$ emissions due to energy consumption for space cooling in each case, and the differences between the cases (greening and no-greening cases) were plotted in Figure 5. This figure shows the average value of $\mathrm{CO}_{2}$ emissions for the entire district. There was a peak in $\mathrm{CO}_{2}$ emissions and a peak in $\mathrm{CO}_{2}$ reduction by greening in the morning when the cooling load in the office was high. In terms of daily accumulated values, the $\mathrm{CO}_{2}$ reduction effect (the differences between the greening and no-greening cases) was $2.93\left(\mathrm{~kg}-\mathrm{CO}_{2} / \mathrm{d}\right)$ in the $100 \%$ greening case, and $1.47\left(\mathrm{~kg}-\mathrm{CO}_{2} / \mathrm{d}\right)$ in the $50 \%$ greening case. The maximum $\mathrm{CO}_{2}$ reduction effect was $1.4 \%$ in the $100 \%$ greening case. The studied cases consider six-floor buildings. Therefore, for the entire building, the reduction effect is not necessarily large.

(a) $\mathrm{CO}_{2}$ emissions

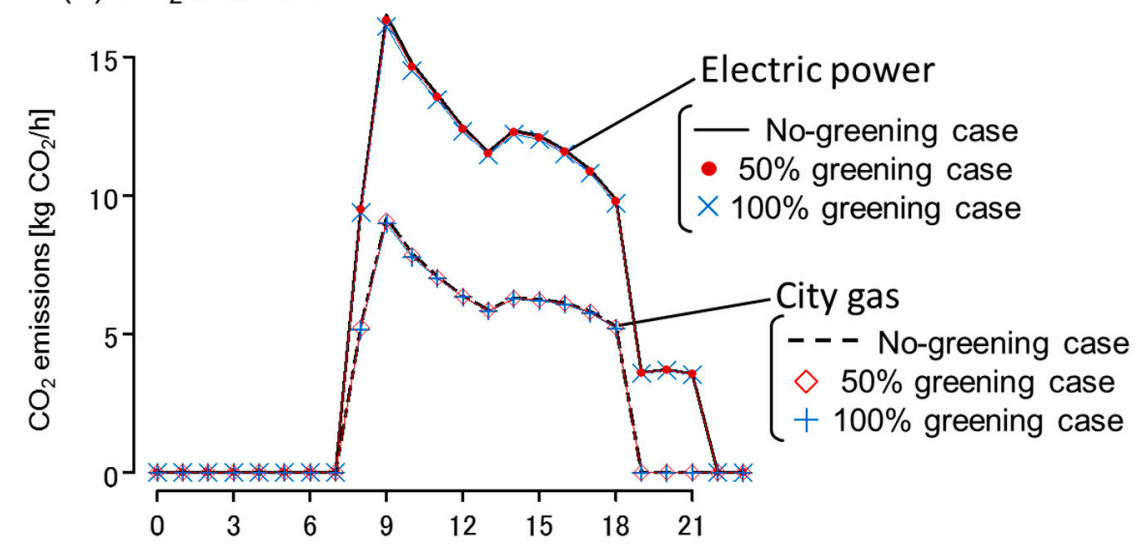

(b) Comparison with the no-greening case

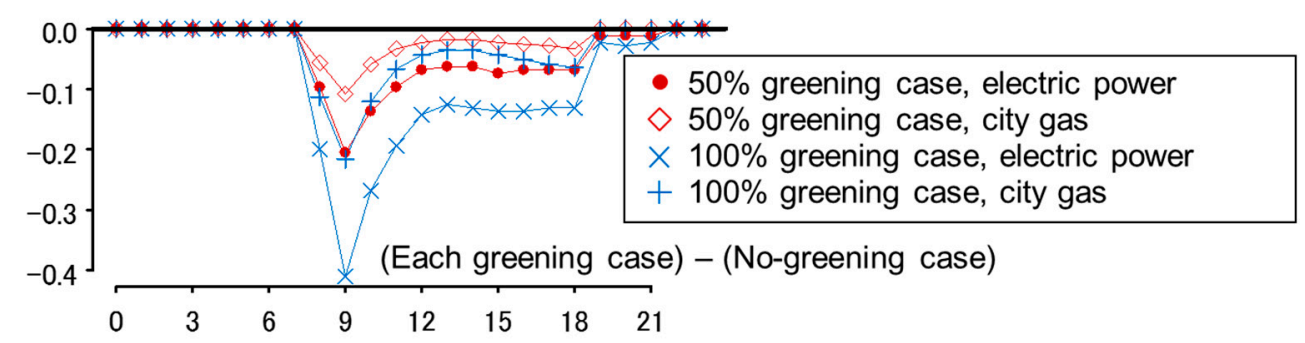

Figure 5. $\mathrm{CO}_{2}$ emissions in greening and no-greening cases and their differences.

In order to quantify the factors underlying these energy savings and $\mathrm{CO}_{2}$ reduction effects, the respective heat balances and differences between the two were plotted for the $100 \%$ greening case and no-greening case in Figure 6 . In the 50\% greening case, the results were intermediate 
between the two cases. The direction in which heat enters the indoor space was assumed to be positive. The removed sensible heat and removed latent heat, indicated as negative values, were the quantities of heat removed by the air-conditioning equipment as sensible heat load and latent heat load, respectively. The graph of the differences between the two cases in Figure $6 c$ shows a particular reduction in heat conduction from roof and walls. Since the removed quantity of heat was negative, the difference graph indicates a load reduction when the value was positive. Therefore, as seen in Figure $6 c$, the removed sensible heat decreased with heat conduction, whereas the removed latent heat increased to some extent because the outside humidity increased with roof greening. There was a slight increase in the heat infiltration through ventilation under the assumed conditions of this study. There was a greater increase in latent heat load because of the rise in humidity than a decrease in sensible heat load caused by the decrease in temperature. However, the increase in removed latent heat owing to the roof greening was smaller than the reduction of removed sensible heat. Therefore, the comparison done by combining heat conduction and heat infiltration through ventilation shows that the cooling load decreases due to roof greening.

(a) No-greening case

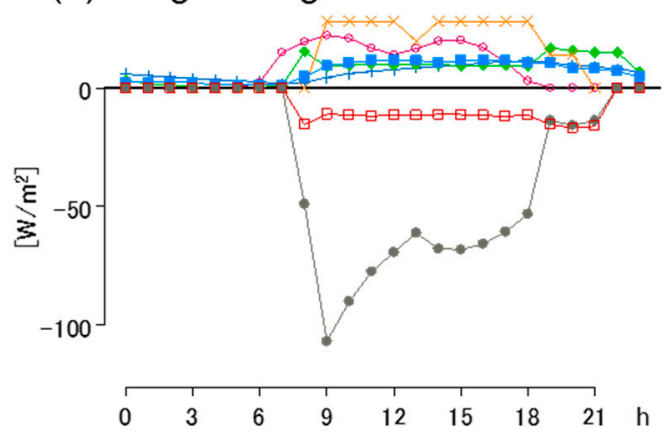

(c) Difference between the two cases

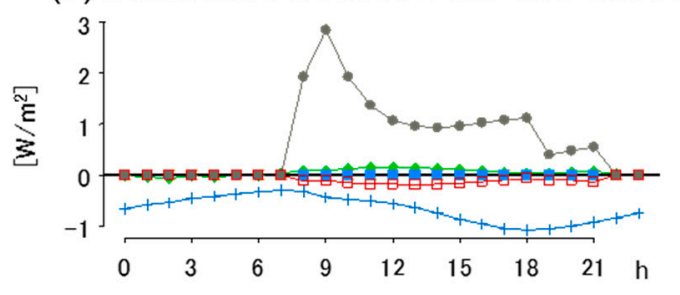

(b) $100 \%$ greening case

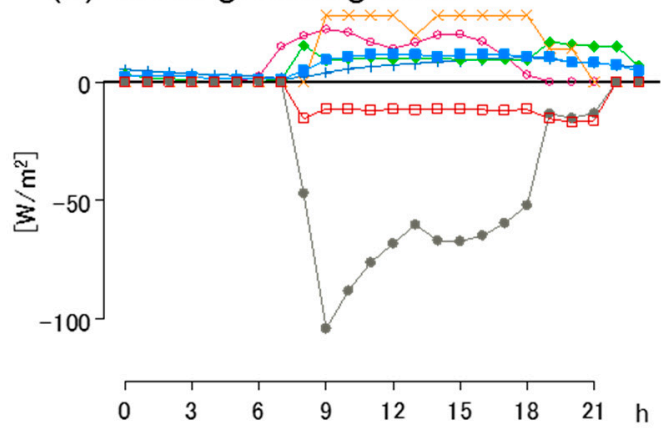

Figure 6. Calculation results for indoor heat balance in the $100 \%$ greening case and the no-greening case, and the difference between the two cases.

For a more detailed analysis of the changes in conductive heat and heat infiltration through ventilation, the conductive heat was divided into wall surface, rooftop, and heat infiltration through ventilation, which was further divided into sensible and latent heat. The daily average values per floor area were indicated in a bar graph (Figure 7). There was a significant reduction in conductive heat from the rooftop due to greening. Although the total amount of conductive heat from wall surfaces was high, the reduction effect due to greening was extremely small. In heat infiltration through ventilation, the total increase in latent heat due to increased humidity was greater than the total reduction in sensible heat due decreased temperature (Figure 7). The decrease in surface temperature on the roof surface was approximately $10{ }^{\circ} \mathrm{C}$ during the day (Figure 2), and the maximum decrease in air temperature was $0.13^{\circ} \mathrm{C}$ (Figure 4). 


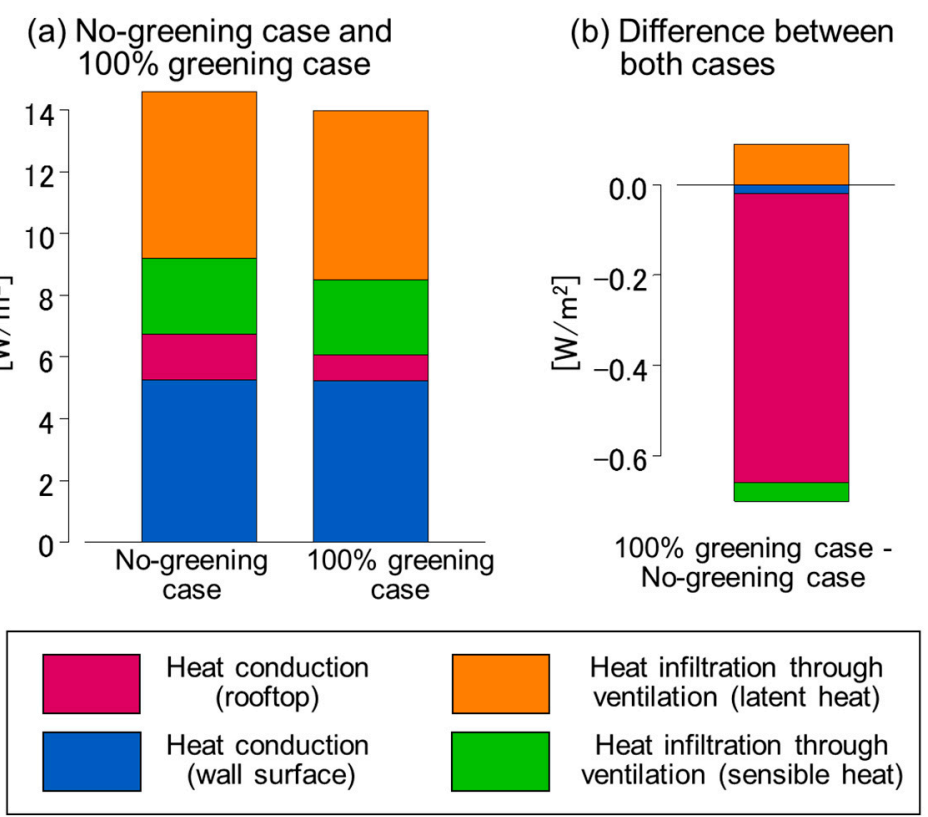

Figure 7. Detailed comparison of transmitted heat and heat introduced through ventilation (daily average per floor area).

Based on these results, the conductive heat from the rooftop was considered a direct effect of the reduction in roof surface temperature. The conductive heat from wall surfaces and heat infiltration through ventilation were considered an indirect effect of the outside air. The increase in heat infiltration through ventilation due to latent heat was greater than the conductive heat and heat infiltration through ventilation combined. This suggests that, when a green roof was installed, the effect of an increase in latent heat load was greater than the effect in which the sensible heat load was reduced in surrounding buildings. This conclusion conflicts with the common notion that roof greening mitigates the UHI effect and reduces the energy consumption for cooling. However, it is not appropriate to generalize this result because, in practice, the effects depend on weather and applicable building conditions. The direct and indirect effects were not separately analyzed in this study, and the $\mathrm{CO}_{2}$ reduction effect obtained as a result of both effects was the subject of evaluation.

$\mathrm{CO}_{2}$ emissions from irrigation were calculated based on the assumption that the amount of water needed for evapotranspiration was supplied by the waterworks. The $\mathrm{CO}_{2}$ emissions from powering the pumps to lift water to the roof and from the use of tap water were considered. Pump power was calculated by setting the pump efficiency at 0.6 and assuming the rooftop height to be the lifting height. For tap water, the calculation was performed with $\mathrm{CO}_{2}$ emissions of $0.193\left(\mathrm{~kg}-\mathrm{CO}_{2} / \mathrm{m}^{3}\right)$ for water purification, delivery and distribution, based on the estimations by Genchi et al. [58]. $\mathrm{CO}_{2}$ emissions for each case were shown in Figure 8. For comparison, $\mathrm{CO}_{2}$ reduction by the cooling effect of green roofs shown in Figure 5 were added to Figure 8.

$\mathrm{CO}_{2}$ emissions from the tap water use $\left(0.21\left(\mathrm{~kg}-\mathrm{CO}_{2} / \mathrm{d}\right)\right.$ in the $100 \%$ greening case and $0.11\left(\mathrm{~kg}-\mathrm{CO}_{2} / \mathrm{d}\right)$ in the $50 \%$ greening case) were greater than $\mathrm{CO}_{2}$ emissions from powering the pumps $\left(0.038\left(\mathrm{~kg}-\mathrm{CO}_{2} / \mathrm{d}\right)\right.$ in the $100 \%$ greening case and $0.020\left(\mathrm{~kg}-\mathrm{CO}_{2} / \mathrm{d}\right)$ in the $50 \%$ greening case $)$ (Figure 8). These values account for $8-9 \%$ of the $\mathrm{CO}_{2}$ reduction by the cooling effect of green roofs. Under the calculation conditions of this study, it can be concluded that a $\mathrm{CO}_{2}$ reduction effect can be obtained by using green roofs, even considering the $\mathrm{CO}_{2}$ emissions from irrigation. 


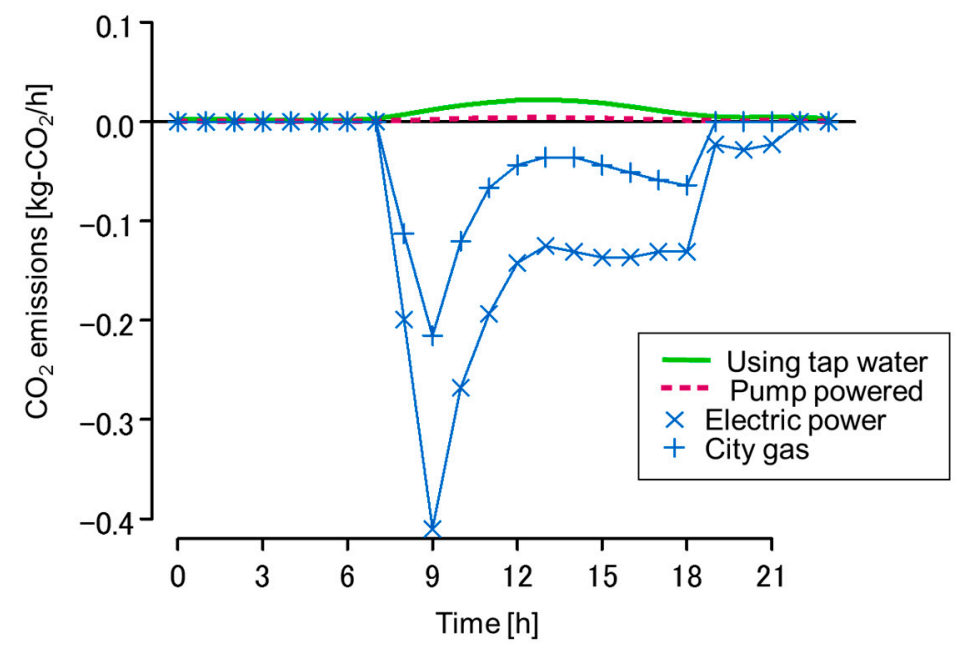

Figure 8. $\mathrm{CO}_{2}$ emissions due to irrigation and $\mathrm{CO}_{2}$ reductions for cooling in the $100 \%$ greening case.

\section{Evaluation under Various Calculation Conditions}

The relationships between evapotranspiration, $\mathrm{UHI}$ mitigation, and $\mathrm{CO}_{2}$ reduction were investigated using the calculation results presented in Section 4. These relationships depend on the assumed building conditions, which were considered standard conditions hereafter. From these assumed parameters, heat insulation, performance of the roof and evaporation efficiency at the green roof area were likely to significantly affect the results. Therefore, an investigation was conducted considering variations of these two parameters, a high insulation condition, and a low evaporation efficiency condition. For the high insulation condition, the roof insulation material was assumed to be equivalent to the next generation energy savings standard, similar to the high insulation cases by Kikegawa et al. [40], and Hirano and Fujita [42]. The coefficients of heat transmission and heat capacity per cross-sectional area were set to $0.38\left(\mathrm{~W} / \mathrm{m}^{2} / \mathrm{K}\right)$ and $2.12 \times 105\left(\mathrm{~J} / \mathrm{m}^{2} / \mathrm{K}\right)$, respectively. In addition, similar to the standard conditions, the green roof ratio varied among $0 \%, 50 \%$, and $100 \%$.

Specific values related to roof insulation were provided by Kikegawa et al. [40]. In this study, only roof changes were considered. Changes in wall surfaces to analyze the influence of factors other than roof greening were not studied. The values, other than the roof insulation performance were the same as the standard conditions.

In the low evaporation efficiency scenario, the evaporation efficiency at greening areas, which was set as 0.2 in the standard conditions, was changed at regular intervals from 0.0 to 0.2 , instead of changing the vegetation cover ratio. The remaining factors were the same as in the $100 \%$ greening case under standard conditions.

Figure 9 shows the relationship between evapotranspiration and temperature reduction, and Figure 10 shows the relationship between watering and $\mathrm{CO}_{2}$ emissions. Differences between the greening and no-greening cases were plotted under standard, high insulation, and low evaporation efficiency (evaporation efficiency is 0) conditions. As seen in Figure 9, the differences regarding the temperature reduction effect were small among all conditions and roughly formed straight lines. It is likely that the temperature decrease in response to evapotranspiration depends almost entirely on atmospheric diffusion, thus, these results are valid. In practice, some differences may appear due to the changes in radiation, heat storage, and air-conditioning. However, because such effects were small in the present study, it was concluded that evapotranspiration is the main influencing factor. Nevertheless, the slopes shown in Figure 9 can change depending on weather conditions. Therefore, for a more accurate future analysis, the same evaluation should be performed under various weather conditions. 


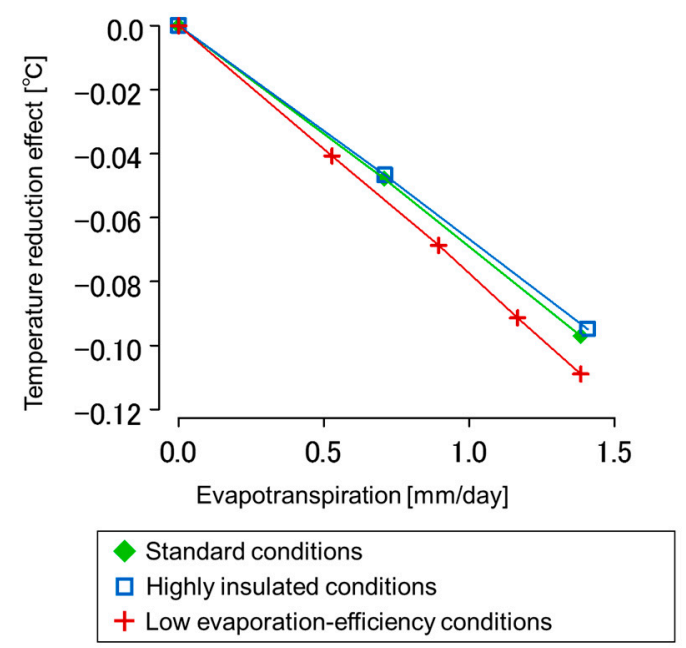

Figure 9. Relationship between evapotranspiration and temperature.

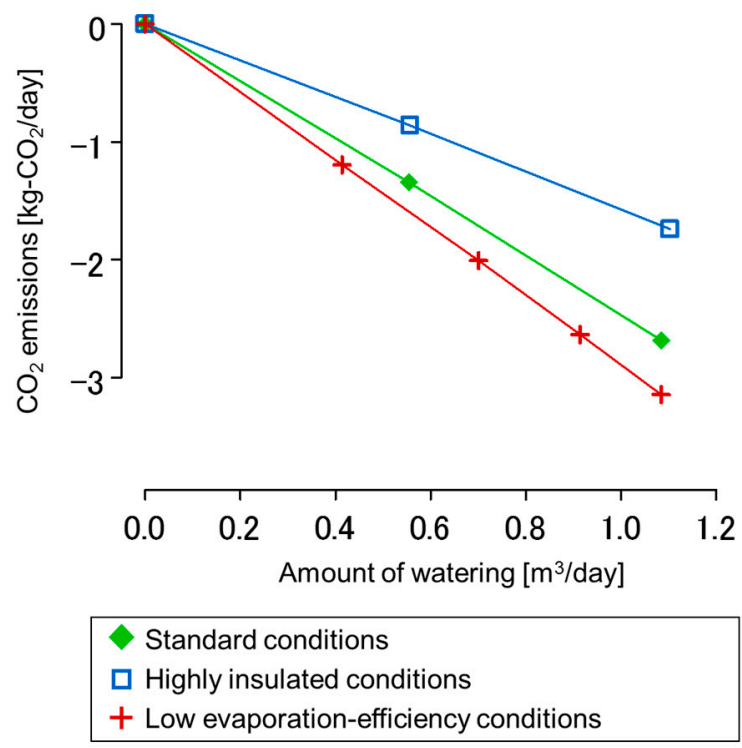

Figure 10. Relationship between amount of watering and $\mathrm{CO}_{2}$ emissions (per building).

Figure 10 shows the net $\mathrm{CO}_{2}$ reduction considering the reduction in cooling energy and $\mathrm{CO}_{2}$ emissions from irrigation. There are no significant differences between the standard and the low evaporation efficiency condition. Figure 7 shows that the reduction in heat conduction was the dominant factor affecting air-conditioning load, and there was a relationship between the increased latent heat flux and decreasing heat conduction. Figure 10 shows that the $\mathrm{CO}_{2}$ reduction effect in response to evapotranspiration was nearly half under highly insulated conditions, compared with the other cases. Therefore, the effectiveness of green roofs showed a strong dependence on building structure and insulation performance of the construction exterior. Therefore, it is necessary to accumulate evaluations of various types of buildings for more general findings in the future.

\section{Conclusions}

In this study, CM-BEM was used to evaluate the effects of roof greening of office buildings in the reduction of $\mathrm{UHI}$ and $\mathrm{CO}_{2}$, considering the necessary amount of water to maintain the green roof.

The main results of this research can be summarized as follows:

(1) The UHI mitigation effect of green roofs was evaluated. Under the assumed conditions and parameters of this study, the maximum air temperature decrease of large-scale green roofs was 
$0.13^{\circ} \mathrm{C}$. The relationship between this air temperature decrease and evapotranspiration was also determined.

(2) The $\mathrm{CO}_{2}$ reduction effect of green roofs was evaluated. In particular, the evaluation considered $\mathrm{CO}_{2}$ reduction by lower cooling energy consumption and $\mathrm{CO}_{2}$ emissions due to powering the pumps and using waterworks for irrigation. The $\mathrm{CO}_{2}$ reduction due to cooling energy saving was greater than $\mathrm{CO}_{2}$ emissions from irrigation, in terms of the direct effects of the reduction in surface temperature. $\mathrm{A} \mathrm{CO}_{2}$ reduction effect could be achieved in buildings where green roofs were installed. However, the indirect effects of the outside air could significantly impact $\mathrm{CO}_{2}$ emissions due to the latent heat load. Therefore, the effects on surrounding buildings should be considered in the future.

(3) In addition to the standard conditions, we considered conditions in which the roof insulation performance and evaporation efficiency of the green roof area varied. The results were compared with the standard conditions. The relationships between water amount, $\mathrm{UHI}$ mitigation, and $\mathrm{CO}_{2}$ reduction, were investigated under each calculation conditions.

Under the standard conditions, the evaporation efficiency of the green roof surface was set as 0.2 , but this was a value measured with sedum planting and no watering during the day [30]. Therefore, it can be considered a conservative value for green roofs. In practice, a larger effect can likely be obtained by increasing the amount of watering.

A suggestion for future research in this area is to incorporate a detailed water balance model that considers precipitation and water retention effectiveness of the soil layer. In this research we evaluated the effect of green roof by quantifying the evapotranspiration using the latent heat flux and considering the necessary amount of watering. This is a useful method considering that, in previous studies, heat balance calculations were carried out, whereas the water supply amount was left unknown, even for building rooftops where watering was done artificially. However, in practice, artificial watering increases evapotranspiration regardless of vegetation [30], thus, the calculations alone may not show the true value of green roofs. If the current urban cover of the Earth's surface was considered, it would be important to provide water retention capacity of roof surfaces. Therefore, in the future, it would be necessary to conduct a more detailed evaluation considering the water balance of green roof areas, by incorporating precipitation and water retention effectiveness into the thermal environment simulation model.

Another topic for future studies is the direct effect of decreased roof surface temperature and indirect effects of outside air. The energy savings effect of green roofs has already been verified in previous models [39-42,48-51], but it is difficult to use these models for conditions where there is a mixture of buildings with and without green roofs in the same district. Previous studies assumed that there was a large direct effect of the reduction in surface temperature, but the indirect effect of outside air has not been adequately considered. In practice, it is difficult to implement the same green roof in all buildings in a district. Therefore, to evaluate the effects on the surrounding buildings, it is essential to distinguish these direct and indirect effects. In this research, a preliminary evaluation was performed to distinguish direct and indirect effects based on the calculated indoor heat balance (Figure 7). The results suggest that, for indirect effects, under the assumed conditions and parameters of this research, the increase in latent heat load due to increased humidity was greater than the decrease in sensible heat load due to decreased temperature. This is an important result that implies that, if a green roof is installed at a certain building, there is a possibility that the air-conditioning load of the surrounding buildings may increase rather than decrease. However, in practice, these results depend on weather conditions and the condition of the evaluated buildings. Therefore, it is not appropriate to make generalizations based only on the obtained results. In particular, the rates of conductive heat and heat infiltration through ventilation have a strong dependence on the building scale and insulation performance. The coefficient of performance (COP) of air-conditioning equipment varies with sensible and latent heat loads. Therefore, further studies considering these factors are necessary. 
Author Contributions: Conceptualization, Y.H.; Methodology, Y.H. and T.I.; Validation, Y.H. and T.I.; Formal Analysis, Y.H.; Investigation, Y.H.; Writing-Original Draft Preparation, Y.H.; Writing-Review \& Editing, Y.H. and T.I.; Visualization, Y.H.; Supervision, T.I., K.G. and T.F.; Project Administration, K.G. and T.F.; Funding Acquisition, K.G. and T.F.

Funding: This research was funded by Ministry of the Environment, Low Carbon Technology Assessment Program.

Acknowledgments: During this research, we received guidance from Yukihiro Kikegawa of Meisei University, Yukitaka Ohashi of Okayama University of Science, and Toshiaki Ichinose of the Center for Social and Environmental Systems Research, National Institute for Environmental Studies.

Conflicts of Interest: The authors declare no conflict of interest.

\section{References}

1. National Institute for Environmental Studies. 2050 Low-Carbon Society Scenario. Available online: http: / /2050.nies.go.jp/LCS/eng/japan.html (accessed on 16 January 2018).

2. Murakami, S.; Levine, M.d.; Yoshino, H.; Inoue, T.; Ikaga, T.; Shimoda, Y.; Miura, S.; Sera, T.; Nishio, M.; Sakamoto, Y.; et al. Overview of energy consumption and GHG mitigation technologies in the building sector of Japan. Energy Effic. 2009, 2, 179-194. [CrossRef]

3. Ichinose, T.; Matsumoto, F.; Kataoka, K. Chapter 15-Counteracting Urban Heat Islands in Japan. In Book Urban Energy Transition; Droege, P., Ed.; Elsevier: Amsterdam, The Netherlands, 2008; pp. 365-380. [CrossRef]

4. Rizwan, A.M.; Dennis, L.Y.C.; Liu, C. A review on the generation, determination and mitigation of Urban Heat Island. J. Environ. Sci. 2008, 20, 120-128. [CrossRef]

5. Santamouris, M. On the energy impact of urban heat island and global warming on buildings. Energy Build. 2014, 82, 100-113. [CrossRef]

6. Santamouris, M.; Cartalis, C.; Synnefa, A.; Kolokotsa, D. On the impact of urban heat island and global warming on the power demand and electricity consumption of buildings-A review. Energy Build. 2015, 98, 119-124. [CrossRef]

7. Akbari, H.; Kolokotsa, D. Three decades of urban heat islands and mitigation technologies research. Energy Build. 2016, 133, 834-842. [CrossRef]

8. Huang, Q.; Lu, Y. Urban heat island research from 1991 to 2015: A bibliometric analysis. Theor. Appl. Climatol. 2018, 131, 1055-1067. [CrossRef]

9. Mauree, D.; Coccolo, S.; Perera, A.T.D.; Nik, V.; Scartezzini, J.-L.; Naboni, E. A New Framework to Evaluate Urban Design Using Urban Microclimatic Modeling in Future Climatic Conditions. Sustainability 2018, 10, 1134. [CrossRef]

10. Frank, T. Climate change impacts on building heating and cooling energy demand in Switzerland. Energy Build. 2005, 37, 1175-1185. [CrossRef]

11. Castleton, H.F.; Stovin, V.; Beck, S.B.M.; Davison, J.B. Green roofs; building energy savings and the potential for retrofit. Energy Build. 2010, 42, 1582-1591. [CrossRef]

12. Santamouris, M. Cooling the cities-A review of reflective and green roof mitigation technologies to fight heat island and improve comfort in urban environments. Sol. Energy 2014, 103, 682-703. [CrossRef]

13. Li, Y.; Babcock, R.W. Green roofs against pollution and climate change. A review. Agron. Sustain. Dev. 2014, 34, 695-705. [CrossRef]

14. Viola, S. Green roofs for built environment recovery: Technological transitions. J. Clean. Prod. 2017, 153, 592-599. [CrossRef]

15. Xiao, M.; Lin, Y.; Han, J.; Zhang, G. A Review of Green Roofs Research and Development in China. Renew. Sustain. Energy Rev. 2014, 40, 633-648. [CrossRef]

16. Francis, L.F.M.; Jensen, M.B. Benefits of green roofs: A systematic review of the evidence for three ecosystem services. Urban For. Urban Green. 2017, 28, 167-176. [CrossRef]

17. Besir, A.B.; Cuce, E. Green roofs and facades: A comprehensive review. Renew. Sustain. Energy Rev. 2018, 82, 915-939. [CrossRef]

18. Izumi, T.; Matsuyama, H. Estimation of rooftop area and potential area for rooftop greening in tokyo metropolitan area. J. Archit. Plan. 2004, 581, 83-88. (In Japanese) [CrossRef]

19. Tsubomatsu, M.; Fukazawa, T. A study on estimation of area available for rooftop tree-planting in terms of aerial photograph. Pap. Environ. Inf. Sci. 2002, 16, 399-404. (In Japanese) 
20. Kazak, J.K. The use of a decision support system for sustainable urbanization and thermal comfort in adaptation to climate change actions-The case of the Wroclaw Larger Urban Zone (Poland). Sustainability 2018, 10, 1083. [CrossRef]

21. Takebayashi, H.; Moriyama, M. Surface heat budget on green roof and high reflection roof for mitigation of urban heat island. Build. Environ. 2007, 42, 2971-2979. [CrossRef]

22. Ayata, T.; Tabares-Velasco, P.C.; Srebric, J. An investigation of sensible heat fluxes at a green roof in a laboratory setup. Build. Environ. 2011, 46, 1851-1861. [CrossRef]

23. Huang, Y.-Y.; Chen, C.-T.; Liu, W.-T. Thermal performance of extensive green roofs in a subtropical metropolitan area. Energy Build. 2018, 159, 39-53. [CrossRef]

24. Coutts, A.M.; Daly, E.; Beringer, J.; Tapper, N.J. Assessing practical measures to reduce urban heat: Green and cool roofs. Build. Environ. 2013, 70, 266-276. [CrossRef]

25. Collins, S.; Kuoppamaki, K.; Kotze, D.J.; Lu, X. Thermal behavior of green roofs under Nordic winter conditions. Build. Environ. 2017, 122, 206-214. [CrossRef]

26. Dvorak, B.; Volder, A. Rooftop temperature reduction from unirrigated modular green roofs in south-central Texas. Urban For. Urban Green. 2013, 12, 28-35. [CrossRef]

27. Jiang, L.; Tang, M. Thermal analysis of extensive green roofs combined with night ventilation for space cooling. Energy Build. 2017, 156, 238-249. [CrossRef]

28. Wong, N.H.; Chen, Y.; Ong, C.L.; Sia, A. Investigation of thermal benefits of rooftop garden in the tropical environment. Build. Environ. 2003, 38, 261-270. [CrossRef]

29. Hagishima, A.; Narita, K.; Tanimoto, J.; Misaka, I.; Matsushima, A.; Onoue, M. Field measurement on the micro climate around the building with the large stepped roof garden the large stepped roof garden. J. Environ. Eng. 2004, 577, 47-54. (In Japanese) [CrossRef]

30. Hirano, Y.; Ichinose, T. Observation and characterization of the surface heat budget on a rooftop planted with Sedum. Environ. Eng. Res. 2006, 43, 661-672. (In Japanese)

31. Bevilacqua, P.; Coma, J.; Perez, G.; Chocarro, C.; Juarez, A.; Sole, C.; De Simone, M.; Cabeza, L.F. Plant cover and floristic composition effect on thermal behaviour of extensive green roofs. Build. Environ. 2015, 92, 305-316. [CrossRef]

32. Squier, M.; Davidson, C.I. Heat flux and seasonal thermal performance of an extensive green roof. Build. Environ. 2016, 107, 235-244. [CrossRef]

33. Tam, V.W.Y.; Wang, J.; Le, K.N. Thermal insulation and cost effectiveness of green-roof systems: An empirical study in Hong Kong. Build. Environ. 2016, 110, 46-54. [CrossRef]

34. Wong, N.H.; Cheong, D.K.W.; Yan, H.; Soh, J.; Ong, C.L.; Sia, A. The effects of rooftop garden on energy consumption of a commercial building in Singapore. Energy Build. 2003, 35, 353-364. [CrossRef]

35. Krpo, A.; Salamanca, F.; Martilli, A.; Clappier, A. On the impact of anthropogenic heat fluxes on the urban boundary layer: A two-dimensional numerical study. Bound.-Layer Meteorol. 2010, 136, 105-127. [CrossRef]

36. Salamanca, F.; Krpo, A.; Martilli, A.; Clappier, A. A new building energy model coupled with an urban canopy parameterization for urban climate simulations-Part I. formulation, verification, and sensitivity analysis of the model. Theor. Appl. Climatol. 2010, 99, 331. [CrossRef]

37. Mauree, D.; Coccolo, S.; Kaempf, J.; Scartezzini, J.L. Multi-scale modelling to evaluate building energy consumption at the neighbourhood scale. PLOS ONE 2017, 12, e0183437. [CrossRef]

38. Salamanca, F.; Georgescu, M.; Mahalov, A.; Moustaoui, M.; Wang, M.; Svoma, B.M. Assessing summertime urban air conditioning consumption in a semiarid environment. Environ. Res. Lett. 2013, 8, 034022. [CrossRef]

39. Watanabe, T.; Izumi, T.; Matsuyama, H. Numerical study on effects of rooftop greening on moderating air temperature in Tokyo metropolitan area. J. Jpn. Soc. Civ. Eng. Ser. G 2011, 67, 101-113. (In Japanese)

40. Kikegawa, Y.; Genchi, Y.; Kondo, H.; Hanaki, K. Impacts of city-block-scale countermeasures against urban heat-island phenomena upon a building's energy-consumption for air-conditioning. Appl. Energy 2006, 83, 649-668. [CrossRef]

41. Ohashi, Y.; Ihara, T.; Kikegawa, Y.; Sugiyama, N. Numerical simulations of influence of heat island countermeasures on outdoor human heat stress in the 23 wards of Tokyo, Japan. Energy Build. 2016, 114, 104-111. [CrossRef]

42. Hirano, Y.; Fujita, T. Simulating the $\mathrm{CO}_{2}$ reduction caused by decreasing the air conditioning load in an urban area. Energy Build. 2016, 114, 87-95. [CrossRef] 
43. Hirano, Y.; Tanikawa, H.; Fujita, T. Numerical simulation of rooftop evapotranspiration and $\mathrm{CO}_{2}$ reduction effects of buildings with green roofs. J. Jpn. Soc. Civ. Eng. 2015, 71, I_439-I_444. (In Japanese)

44. Kondo, H.; Genchi, Y.; Kikegawa, Y.; Ohashi, Y.; Yoshikado, H.; Komiyama, H. Development of a multi-layer urban canopy model for the analysis of energy consumption in a big city: Structure of the urban canopy model and its basic performance. Bound.-Layer Meteorol. 2005, 116, 395-421. [CrossRef]

45. Kikegawa, Y.; Genchi, Y.; Yoshikado, H.; Kondo, H. Development of a numerical simulation system toward comprehensive assessments of urban warming countermeasures including their impacts upon the urban buildings' energy-demands. Appl. Energy 2003, 76, 449-466. [CrossRef]

46. Ohashi, Y.; Genchi, Y.; Kondo, H.; Kikegawa, Y.; Yoshikado, H.; Hirano, Y. Influence of air-conditioning waste heat on air temperature in Tokyo office areas during summer: Numerical experiments using an urban canopy model coupled with a building energy model. J. Appl. Meteorol. Climatol. 2007, 46, 66-81. [CrossRef]

47. Hirano, Y.; Yoshida, Y. Assessing the effects of $\mathrm{CO}_{2}$ reduction strategies on heat islands in urban areas. Sustain. Cities Soc. 2016, 26, 383-392. [CrossRef]

48. Hirano, Y.; Fujita, T.; Bunya, S.; Inoue, T. Examination of how various measures in urban districts affect the development of low carbon cities-A case study of cooling energy savings in the city of Kawasaki. Environ. Sci. 2011, 24, 255-268. (In Japanese)

49. Tanimoto, J.; Hagishima, A.; Chimklai, P. An approach for coupled simulation of building thermal effects and urban climatology. Energy Build. 2004, 36, 781-793. [CrossRef]

50. Ashie, Y.; Ca, V.T.; Asaeda, T. Building canopy model for the analysis of urban climate. J. Wind Eng. Ind. Aerodyn. 1999, 81, 237-248. [CrossRef]

51. Yoon, S.; Ashie, Y. Numerical simulation on the summer thermal environmental alleviation effect by urban planting in a coastal local city-Case study in Zushi city. J. Environ. Eng. 2004, 577, 41-56. (In Japanese) [CrossRef]

52. Pigeon, G.; Legain, D.; Durand, P.; Masson, V. Anthropogenic heat release in an old European agglomeration (Toulouse, France). Int. J. Climatol. 2007, 27, 1969-1981. [CrossRef]

53. Hirano, Y.; Fujita, T. Evaluation of the impact of the urban heat island on residential and commercial energy consumption in Tokyo. Energy 2012, 37, 371-383. [CrossRef]

54. Hirano, Y.; Ichinose, T.; Imura, H.; Shiraki, Y. Simulation evaluation of mitigation effect of urban heat island by watering. Annu. J. Hydraul. Eng. 2009, 53, 307-312. (In Japanese)

55. Hirano, Y.; Kikegawa, Y.; Genchi, Y.; Kondo, H. A comparison of the estimation methods used to determine the air temperature sensitivity of energy consumption by air-conditioning and hot water systems in offices and residences. Energy Resour. 2006, 27, 218-224. (In Japanese)

56. Hirano, Y.; Yasuoka, Y.; Ichinose, T. Urban climate simulation by incorporating satellite-derived vegetation cover distribution into a mesoscale meteorological model. Theor. Appl. Climatol. 2004, 79, 175-184. [CrossRef]

57. Hirano, Y.; Fujita, T.; Tonooka, H. A simulation method of surface heat balance in urban area using thermal remote sensing data. Environ. Eng. Res. 2010, 47, 537-544. (In Japanese)

58. Genchi, Y.; Azuma, T.; Ohashi, Y.; Kikegawa, Y.; Inaba, A. Life cycle assessment of countermeasures for urban heat island effect. In Proceedings of the Annual Meeting of Japan Society of Energy and Resources, Osaka, Japan, 10-11 June 2004; Volume 23, pp. 265-268. (In Japanese)

(C) 2019 by the authors. Licensee MDPI, Basel, Switzerland. This article is an open access article distributed under the terms and conditions of the Creative Commons Attribution (CC BY) license (http://creativecommons.org/licenses/by/4.0/). 